\title{
2 軸圧縮条件下における粒状体内ひずみの空間自己相関特性
}

\author{
Spatial Autocorrelation of Strain in Granular Media under Biaxial Compression Condition
}

並河 努*

Tsutomu Namikawa

\section{*正会員 工博 神戸市立工業高等専門学校准教授 都市工学科（广651-2194 神戸市西区学園東町 8-3）}

\begin{abstract}
Spatial distributions of strains in granular media were investigated by numerically simulating an idealized assembly of two-dimensional particles. The objective of this investigation is to provide insight into the change in the microstructure of granular materials during a loading process. In particular, the spatial association of the relative displacements of particles during the loading process was examined by the spatial analysis. The distinct element method was used for simulating an idealized assembly. Using the calculated relative displacements of the particle, the local strain increments were calculated within triangle elements which were defined by particle centers. The spatial analysis indicated that the spatial autocorrelation distance of the local strain increment varied during the loading process and the strain localization zone occurred prior to the peak stress ratio.
\end{abstract}

Key Words: Gramular Media, Spatial Distribution, Autocorrelation, Distinct Element Method キーワード: 粒状体, 空間分布，自己相関，個別要素法

\section{1.はじめに}

砂質土は多くの砂粒子により構成されており、全体変形 は各粒子の動きに支配される。しかしながら、砂質土の挙 動を評価する場合、粒子個々の動きを評価することは難し く、全体が粒子の集合としての連続体と仮定されるのが一 般的であり、その力学特性は主に室内試験結果より算定さ れる応力とひずみを用いて調べられてきた。室内試験にお いて応力とひずみを算定する際、供試体の均質性が前提条 件となるが、試験中の供試体内の砂粒子の動きにはばらつ きが存在すると考えられ、特にピーク応力前後においては、 せん断帯といったひずみの局所化領域の発生により均質 性の前提条件が試験中に成立しなくなる。このため、マク ロな視点で捉えた手法により砂質土の力学挙動を評価す る場合において、供試体内の粒子の動きの分布を考慮する ことは重要であると考えられるが、個々の粒子の動きの空 間分布については未だ解明されていない点が多い。

これまで、せん断過程における砂質土のひずみの局所化 形成に関しては、平面ひずみ圧縮試験による研究が行われ てきた (Han and Vardoulakis, 1991 ${ }^{1)}$; Han and Drescher, $1993^{2)}$; Yoshida et al. 1994 ${ }^{3)}$; Finno et al. 19974) ; Alshibli and Sture, $2000^{5)}$; Desrues and Viggiani, 2004 ${ }^{6)}$ など）。しかし ながら、砂質土の室内試験において砂粒子個々の微小な動 きを計測することは非常に困難であるため、砂粒子の動き に関しては、主に個別要素法を用いた数值解析により研究
が行われてきた (Cundall and Strack, 19797) ; Bardet and Proubet, 1991 ${ }^{8)}$; 松岡 and 山本, 19949) ; 岩下 and 小田, $1999^{10)}$; 大村ら 2004 ${ }^{11)}$ など）。これらの研究により、ピ 一ク応力後のせん断帯形成過程における、粒状体内の力の 伝達経路や、せん断帯の内部の粒子挙動に関して多くの知 見が得られている。しかし、載荷初期段階からの粒子変位 の空間分布に関する研究は少なく、載荷中における供試体 内の局所化領域形成に関しては不明な点が多い。

本研究では、砂質土などの粒状体で構成される材料の、 個々の粒子変位の空間分布に関する基礎的な知見を得る ために、個別要素法を用いた 2 次元圧縮試験の数值解析を 実施した。載荷初期からピーク荷重までの供試体内の粒子 の動きより算定されるひずみ分布を計算し、マクロなひず みとの関係を調べた。また、載荷過程におけるひずみの空 間自己相関特性を調べるため、各載荷段階でのひずみの空 間自己相関距離を Moran's $I$ を用いて算定した。さらに、 Local Moran's $I$ を用いてひずみの局所化領域を同定した。 これらの空間統計解析結果より、マクロな応力ーひずみ関 係と粒子個々の動きより算定されるひずみの空間分布の 変化に関する議論を行う。

\section{2. 解析概要}

\section{1 個別要素法}

本研究では、Cundall and Strack(1979)》 により提案された 
個別要素法（DEM）を用いた。DEM では、剛体と仮定し た粒子の接触点において法線方向にはバネとダッシュポ ットを、接線方向にはバネ、ダッシュポット及びスライダ 一を仮定し、各粒子の運動方程式を時間領域で差分近似す ることにより、各時間での粒子の位置を数值解析で追跡す る。本研究では粒状集合体の圧縮条件下における基礎的な 挙動を調べるため、粒子形状は円とし、2 次元での 2 軸圧 縮のシミュレーションを実施した。解析で用いたパラメー タと物性を表-1 に示す。岩下 and 小田(1999) ${ }^{10)}$ の研究で用 いられたパラメータをここでは用いた。これらの值は具体 的な材料において実験的に計測されたものではないが、粒 状体の定性的な挙動を調べることを目的とした研究にお いて実績のあるパラメータであると考えられる。ただし、 本研究では基本的な条件下での粒子の動きの空間分布を 調べることを目的とし、転がり抵抗は考慮しておらず、上 下載荷盤と粒子の摩擦は 0 としている。

供試体は $0.8 \mathrm{~mm}, 1.0 \mathrm{~mm}, 1.2 \mathrm{~mm}$ の直径の粒子より構成さ れている。粒子数は約 3800 個である。粒子の圧密前の初 期配置は以下の手順で行った。約 $50 \mathrm{~mm} \times 100 \mathrm{~mm}$ の領域に、 粒子同士が重ならないように、擬似乱数を用いてランダム に粒子座標を設定する。擬似乱数の生成は、一般的によく 用いられている乗算合同法を用いた。その後、DEMによ り、上下左右の境界をそれぞれ $8 \mathrm{~mm} 、 4 \mathrm{~mm}$ 圧縮方向に移 動させた状況をシミュレーションする。この状態を初期配 置とする。初期配置後、供試体の側方方向に $100 \mathrm{kPa}$ の拘 束圧を負荷する。この際、側方境界には stress-controlled boundary (Bardet and Proubet 1991 ${ }^{8}$ ) を用いる。側方圧縮後 の供試体の状況を図-1 に示す。側方圧縮後、 $1 \times 10^{-2} \mathrm{~mm} / \mathrm{s}$ の速度の変位制御で上下方向に載荷を行う。

\section{2 ひずみの算定}

DEM 解析より得られた粒子の変位を用いて、供試体内 のひずみ分布を算定した。粒子の中心座標を頂点とする Delaunay 三角形分割を実施し (谷口 1992 ${ }^{12}$ ) )、各三角形 要素の頂点の変位より線形の形状関数を用いてひずみを 計算した (図-2 参照)。要素分割された供試体を図-3に 示す。粒子中心に関する Delaunay 分割により算定される ひずみは、個々の粒状体間の相対変位を表す指標といえる。 本研究では個々の粒状体間の相対変位の空間分布を、上記 手法で算定されるひずみを用いて議論する。

表-1 DEM 解析で用いたパラメータ 10)

\begin{tabular}{|l|c|}
\hline Increment of time step & $1.0 \times 10^{-5} \mathrm{~s}$ \\
\hline Particle density & $2600 \mathrm{~kg} / \mathrm{m}^{3}$ \\
\hline Friction coefficient between particles & 0.49 \\
\hline Friction coefficient between particles and wall & 0.00 \\
\hline Normal spring constant & $1.0 \times 10^{8} \mathrm{~N} / \mathrm{m}$ \\
\hline Tangential spring constant & $1.0 \times 10^{7} \mathrm{~N} / \mathrm{m}$ \\
\hline Damping constant & 0.05 \\
\hline
\end{tabular}

ここでは、Delaunay 分割により粒子中心を頂点とする三 角形に関するひずみを用いるが、Delaunay 分割と双対関係 にあるVoronoi 分割を用いる手法もある(佐武 2002 $\left.{ }^{13}\right)$ 。

Voronoi 分割による手法では、間隙を含めた粒子のもつ領 域を定めることができ、粒状体の Voronoi 分割とも呼ばれ ている。

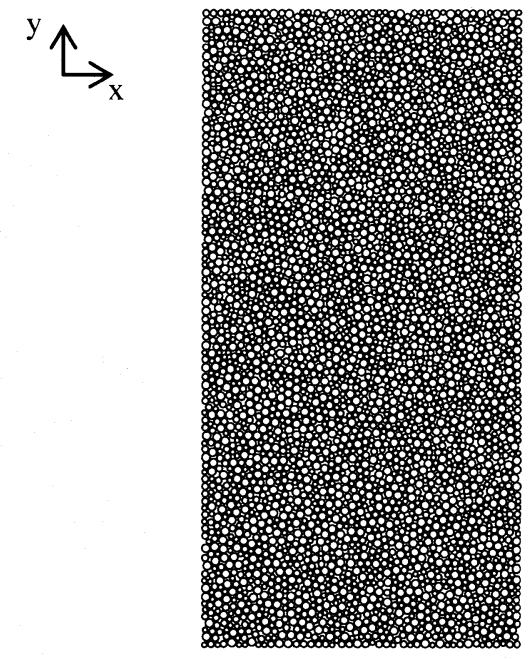

図-1＼cjkstart側方圧縮後の供試体（Case1）

$u_{i}$ : Displacement in $x$ direction $v_{i}:$ Displacement in $y$ direction

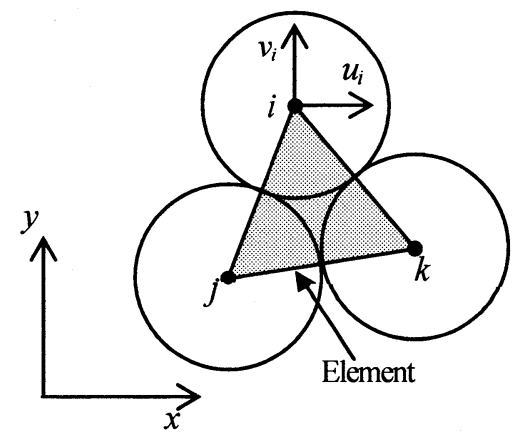

図-2 ひずみの計算方法

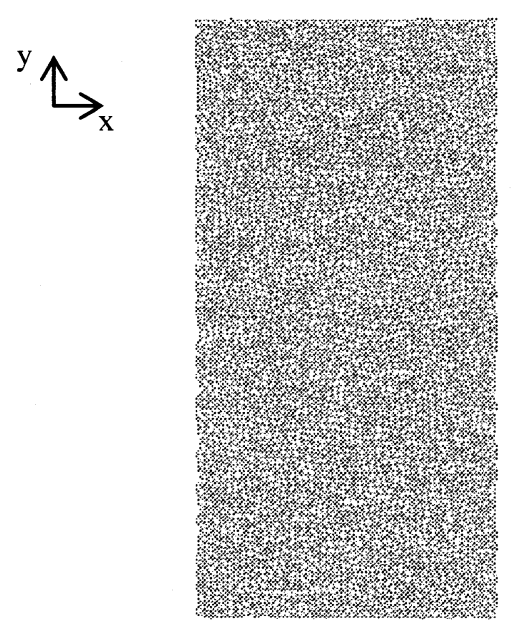

図-3 Delaunay 分割された供試体（Case1） 


\section{3 空間統計解析}

DEM 解析により得られた、ひずみに関して空間統計解 析を実施し、粒子挙動の空間自己相関特性を調べた。ひず み分布のグローバルな空間自己相関性は Moran's $I$ と Geary's $c$ を用いて評価した (Fortin and Dale 200514) )。 Moran’s I, I (d)は次式により表される。

$$
I(d)=\frac{1}{W(d)} \frac{\sum_{\substack{i=1 \\ i \neq j}}^{n} \sum_{\substack{j=1 \\ i \neq j}}^{n} w_{i j}(d)\left(x_{i}-\bar{x}\right)\left(x_{j}-\bar{x}\right)}{\frac{1}{n} \sum_{i=1}^{n}\left(x_{i}-\bar{x}\right)^{2}}
$$

ここで、 $x_{i}$ はデータ值で、 $\bar{x}$ は $x_{i}$ の平均值、 $n$ はデー夕数、 $d$ は離間距離クラス、 $w_{i j}(d)$ は重みである。本研究では、等 間隔の離間距離クラスを設定し、2地点の離間距離が該当 する離間距離クラス内にある場合 $w_{i j}(d)=1$ とし、離間距離 クラス内にない場合 $w_{i j}(d)=0$ とし、Moran's $I$ を算定した。 Moran's Iはピアソン相関係数に対応する指標で、正の相 関を示す場合は 1 以下の正の值を、負の相関を示す場合は -1 以上の負の值を、無相関の場合は 0 を示寸。

Moran'sIはデー夕の平均值を用いているが、平均值を用 いない空間自己相関を表す指標としては、Geary’s $c$ がある。 Geary's $c, c(d)$ は次式により表される。

$$
c(d)=\frac{1}{2 W(d)} \frac{\sum_{\substack{i=1 \\ i \neq j}}^{n} \sum_{\substack{j=1 \\ i \neq j}}^{n} w_{i j}(d)\left(x_{i}-x_{j}\right)^{2}}{\frac{1}{1-n} \sum_{i=1}^{n}\left(x_{i}-\bar{x}\right)^{2}}
$$

Geary's c は標本バリオグラム(Wackernagal 2003 $\left.{ }^{15)}\right)$ を分散 で正規化した值となっており、一般にデータ間の距離 $d$ 大きくなるにつれて 1 に近づく。c(d)の值は 0 から 2 まで 変動し、正の相関が最大で 0 、無相関で 1 、負の相関が最 大で2を示す。

ひずタ分布のローカルな空間自己相関性は LISA（Local indicators for spatial association）として I ocal Moran's $I$ を用 いて評価した(Anselin 1995 ${ }^{16)}$ )。 Local Moran's I, I I (d)は次式 により表される。

$$
I_{i}(d)=\frac{\left(x_{i}-\bar{x}\right)}{\frac{1}{n} \sum_{i=1}^{n}\left(x_{i}-\bar{x}\right)^{2}} \sum_{\substack{j=1 \\ i \neq j}}^{n} w_{i j}(d)\left(x_{j}-\bar{x}\right)
$$

Local Moran's Iは各要素において算定され、その分布を調 べることによりデータ間の相関が強、領域を特定できる。 そのような自己相関の強い領域は局所化領域と考えられ るため、Local Moran's Iにより局所化領域を明確に検出す ることが可能となる。

\section{3. 解析結果}

\section{1 個別要素法の解析結果}

\section{(1) 解析ケース}

解析ケースを表-2 に示寸。初期配置の異なる 2 つのケー スについて約 3800 個の粒子の挙動を調べた。供試体高さ と幅はy 軸方向に載荷前の值である。

\section{（2）マクロな応カーひずみ関係}

軸方向載荷過程における、供試体上下境界の変位より算 定したマクロな応力ーひずみ関係を図4に示す。応力は拘 束圧で正規化している。2 ケースとも載荷初期において、 応力ーひずみ関係はほほ線形関係となっており、応力比が 1.5 を超えたあたりより、非線形性が大きくなっているこ とがわかる。そして、応力比が 1.7 程度までは、 2 ケース の応力ーひずみ関係はほぼ同じとなっている。応力比が 1.7 を超えたあたりよりケース間に差が生じ、Case2 では、 応力比が 1.9 を超えたあたりより、一時的な軟化挙動が生 じるようになる。ただし、一時的な軟化後応力は回復して いる。この軟化挙動を繰り返しながら応力は徐々に増加す る。ピーク荷重時の応力比は各ケースともほぼ同じで、 2.1 程度となっている。

表-2 解析ケース

\begin{tabular}{|c|c|c|c|c|c|c|}
\hline \multirow{2}{*}{ Case } & \multicolumn{3}{|c|}{ 各径の粒子数 } & \multirow{2}{*}{$\begin{array}{c}\text { 高さ } \\
\mathrm{mm}\end{array}$} & $\begin{array}{c}\text { 幅 } \\
\mathrm{mm}\end{array}$ & $\begin{array}{c}\text { 間隙 } \\
\text { 比 }\end{array}$ \\
\cline { 2 - 4 } & $1.2 \mathrm{~mm}$ & $1.0 \mathrm{~mm}$ & $0.8 \mathrm{~mm}$ & & & \\
\hline 1 & 1270 & 1270 & 1286 & 85.68 & 43.26 & 1.13 \\
\hline 2 & 1270 & 1270 & 1262 & 85.40 & 43.09 & 1.14 \\
\hline
\end{tabular}

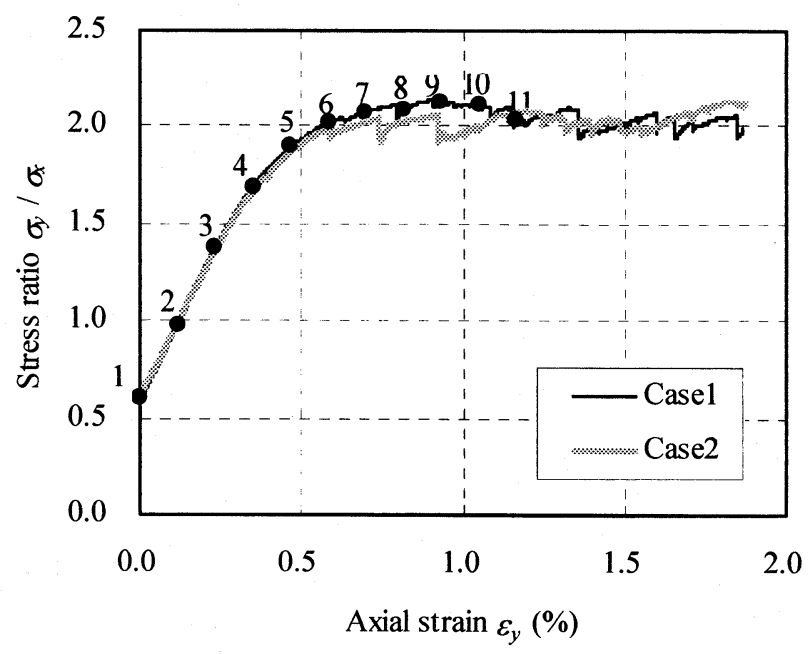

図-4 マクロな応力ーひずみ関係（供試体全体） 


\section{(3) ひずみ分布}

Case1 の応力ーひずみ関係の各段階における、y 方向ひ ずみ増分 $\Delta \varepsilon_{y}$ の分布を図 -5 に示す。各段階の番号は図-4の 応力ーひずみ関係に示した番号と対応している。ここで、

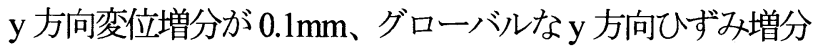
が約 $0.117 \% に$ 対応するひずみ増分を示している。図-5よ り、載荷初期、2-3 段階より局所的に大きなあるいは小さ な $\Delta \varepsilon$, が生じている箇所が点在しており、載荷初期段階で あっても供試体内に均質なひずみが生じていないことが わかる。ただし、大きな $\Delta \varepsilon$ が集中した場所は存在しない。 そして、載荷が進むにつれ供試体内における大きなあるい は小さな $\Delta \varepsilon_{y}$ の分布範囲が広がっている。応力がピークに 達した後の 10-11 段階では、左下端から右側にかけて大き な $\Delta \varepsilon$ 集中している領域が生じていることがわかる。

図-5 と同じ段階における、体積ひずみ増分 $\Delta \varepsilon_{v}$ の分布を 図-6 に示寸。載荷初期段階においても、 $\Delta \varepsilon$ の分布は一様 ではなく、応力がピークに達した後の 10-11 段階では、左 下端から右側にかけて正負の $\Delta \varepsilon$, が集中している領域が生 じている。

図-5 と同じ段階における、偏差ひずみ第 2 不変量増分の 平方根 $\Delta \sqrt{J_{2}^{\prime}}$ の分布を図-7 に示す。 $\Delta \varepsilon_{y}$ の分布と同様に、 載荷初期 2-3 段階より局所的に 1\%を超える大きな偏差ひ ずみ生じている箇所が点在している。応力がピークに近づ き応力一ひずみ関係の非線形性が大きくなる6-7段階では、 右中央から左上にかけておおきなひずみ集中している箇 所が生じている。その後、そのひずみの集中領域は消える が (8-9 段階)、10-11 段階では、新たに左下端から右側に かけてひずみの集中領域が帯状となるいわゆるせん断帯 が生じていることがわかる。

ピーク応力前におけるひずみ増分の局所化領域の形成 と発生箇所の変化は砂の平面ひずみ圧縮試験でも観察さ れて抢り(Finno et al. 19974), Desrues and Viggiani 20049)、本 解析結果はプレピーク時の局所化領域の形成を裹付ける ものとなった。また、ひずみ増分の局所化が顕著となる 6-7 段階は、各ケースの応力ーひずみ関係の差が大きくな る段階と一致しており (図-4 参照)、本解析結果よりプレ ピーク時の局所化領域の形成がマクロな応力ーひずみ関 係に影響を与えることが推測できる。

本研究では、ひずみ増分量の空間分布の夕について検討 を行い、主ひずみの方向についての議論は行わない。主ひ ずみの方向に関しても空間分布特性を把握することが重 要であると考えられるが今後の課題とする。

\section{（4）ひずみの基本統計量}

Casel の各要素のひずみ増分 $\Delta \varepsilon_{\text {人 }} \Delta \sqrt{J_{2}{ }^{\prime}}$ 平均值及び分 散などの基本統計量を表-3 に示す。各段階の番号は図-4 の応力一ひずみ関係に示した番号と対応している。また、 同ケースの 2-3 段階での $\Delta \varepsilon_{\text {人、 }} \Delta \sqrt{J_{2}^{\prime}}$ のヒストグラムを図-8 に示す。

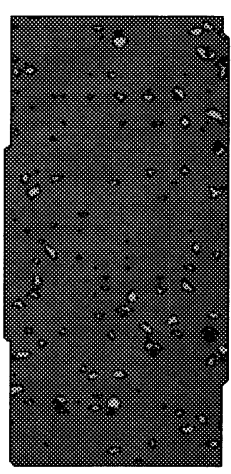

2-3

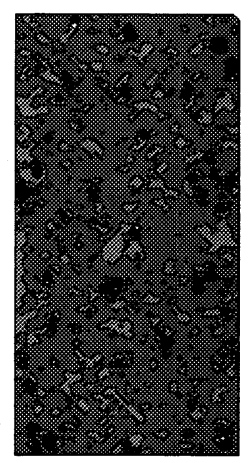

8-9

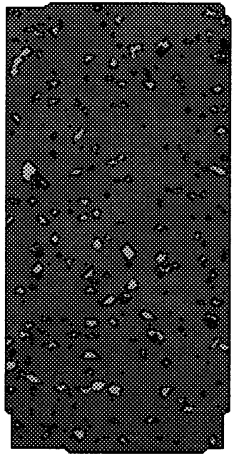

$4-5$

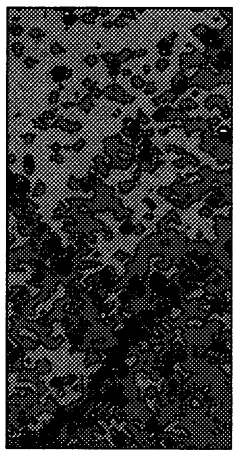

$10-11$

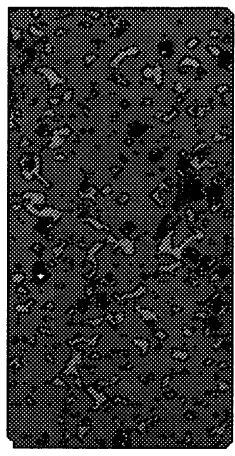

$6-7$

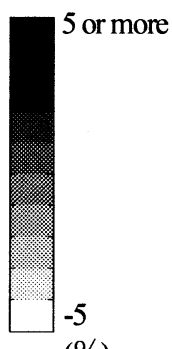

(\%)

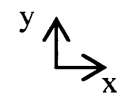

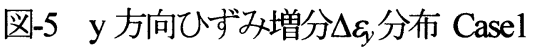

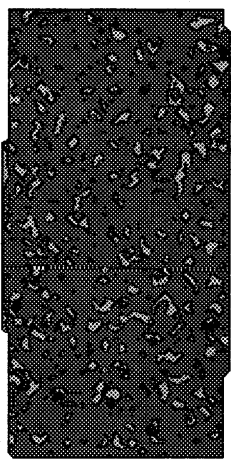

$2-3$

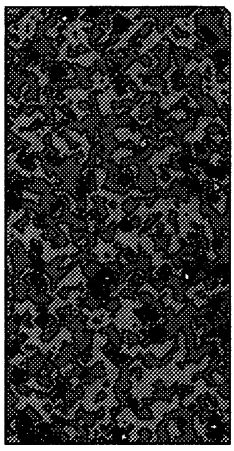

8-9

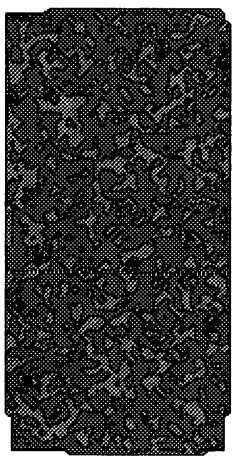

$4-5$

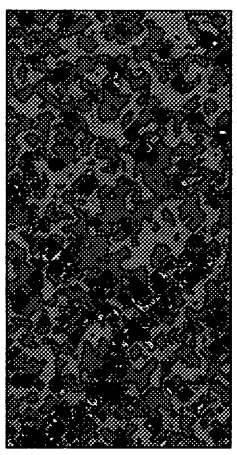

$10-11$

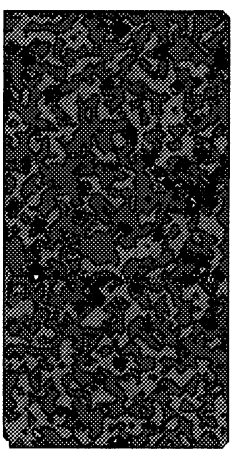

6-7

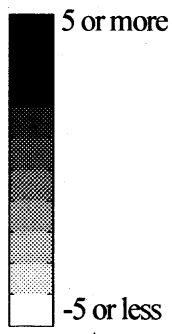

(\%)

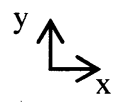

図-6 体積ひずみ増分 $\Delta \varepsilon$ ，分布 Case1 


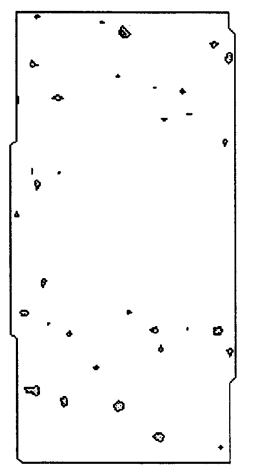

$2-3$

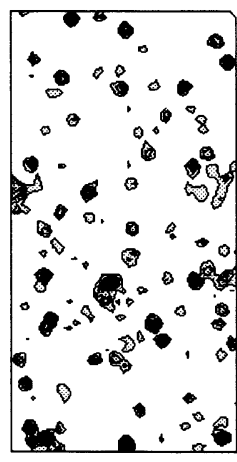

8-9

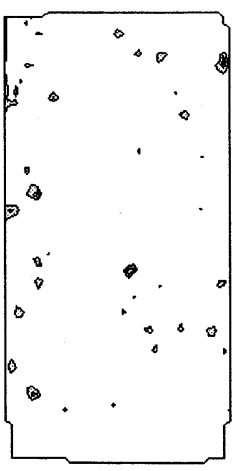

4-5

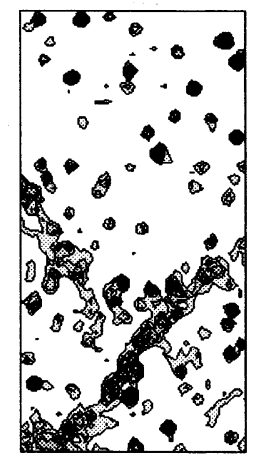

10-11

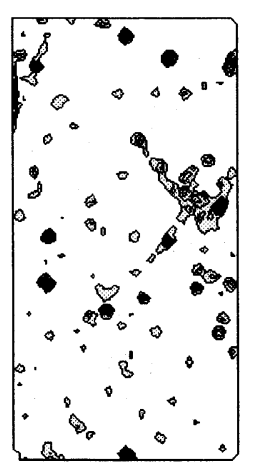

6-7

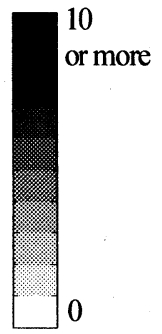

(\%)

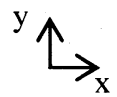

図-7 偏差ひずみ増分 $\Delta \sqrt{J_{2}^{\prime}}$ 分布 Casel

本研究では粒子の中心点を頂点とした三角形要素を Delaunay 分割により生成したため、各要素の面積は異なる。 また、線形の形状関数を用いてひずみを算定しているため、 要素内ひずみの一様性を仮定している。このため、ひずみ の平均值やばらつきを算定する場合、各要素の面積を考慮 する必要があると考えられるが、本研究では各要素の面積 は考慮していない。要素面積の影響に関しては付録で議論 している。

表-3 より、全ての載荷段階において $\Delta \varepsilon_{y}$ の尖度 ${ }^{17)}$ は 30 以上で正規分布（尖度 0 ）に比較して尖りの程度が非常に 大きいことがわかる。尖りの程度が大きいことは、図-8の ヒストグラムからも確認できる。この尖度より $\Delta \varepsilon_{y}$ の分布 が正規分布ではないことがわかる。 $\Delta \sqrt{J_{2}^{\prime}}$ の分布は、各段 階とも正規分布とは大きく異なっており、歪度 ${ }^{17)}$ が 3 以上 と右の裾が長い分布となっている。また、 $\Delta \varepsilon_{y}$ と同様に尖 度も 15 以上と正規分布より尖りの程度が非常に大きい分 布となっている。これらのことは、図-8 のヒストグラムか らも確認できる。

表-3 には各境界変位より算定されるマクロなひずみを 併せて示している。個々の粒状体間の相対変位より算定さ れる $\Delta \varepsilon_{y}$ の平均值は、マクロな $\Delta \varepsilon_{y}$ とほぼ一致している。一 方、個々の粒状体間の相対変位より算定される $\Delta \sqrt{J_{2}{ }^{\prime}}$ の 平均值は、載荷初期よりマクロな $\Delta \sqrt{J_{2}^{\prime}}$ よりかなり大き
くなっており、偏差ひずみ増分においては個々の粒状体間 の相対変位より算定されるひずみの平均值がマクロなひ ずみとは一致しないことがわかる。このことは、プレピー ク挙動においても、マクロな応力ーひずみ関係が粒子レベ ルでの挙動の平均值となっていないことを示している。

表-3 (a)y 方向ひずみ増分 $\Delta \varepsilon_{y}$ の統計量

\begin{tabular}{|c|c|c|c|c|c|}
\hline \multirow{2}{*}{ 載荷 } & \multicolumn{4}{|c|}{$\begin{array}{c}\text { 個々の粒状体間の相対変位より算 } \\
\text { 定されるひずみの統計量 (\%) }\end{array}$} & \multirow{2}{*}{$\begin{array}{l}\text { マクロ } \\
(\%)\end{array}$} \\
\hline & 平均 & 分散 & 歪度 & 尖度 & \\
\hline $2-3$ & 0.116 & 0.0972 & -1.33 & 46.4 & 0.117 \\
\hline $4-5$ & 0.116 & 0.123 & -1.27 & 32.2 & 0.117 \\
\hline $6-7$ & 0.108 & 1.01 & 0.941 & 169 & 0.117 \\
\hline $8-9$ & 0.109 & 1.79 & 1.67 & 111 & 0.118 \\
\hline $10-11$ & 0.104 & 2.18 & 0.165 & 51.2 & 0.118 \\
\hline
\end{tabular}

表-3 (b) 偏差ひずみ増分 $\Delta \sqrt{J_{2}^{\prime}}$ の統計量

\begin{tabular}{|c|c|c|c|c|c|}
\hline \multirow{3}{*}{ 載荷 } & \multirow{2}{*}{\multicolumn{4}{|c|}{$\begin{array}{c}\text { 個々の粒状体間の相対変位より算 } \\
\text { 定されるひずみの統計量 (\%) }\end{array}$}} & \multirow{3}{*}{$\begin{array}{c}\text { マクロ } \\
(\%)\end{array}$} \\
\hline & & & & & \\
\hline & 平均 & 分散 & 歪度 & 尖度 & \\
\hline $2-3$ & 0.176 & 0.0680 & 4.02 & 20.2 & 0.0911 \\
\hline $4-5$ & 0.231 & 0.103 & 3.66 & 19.5 & 0.108 \\
\hline $6-7$ & 0.414 & 0.829 & 6.93 & 73.9 & 0.129 \\
\hline $8-9$ & 0.521 & 1.47 & 7.19 & 75.2 & 0.135 \\
\hline $10-11$ & 0.696 & 1.96 & 3.91 & 19.8 & $\begin{array}{l}0.148 \\
\end{array}$ \\
\hline
\end{tabular}
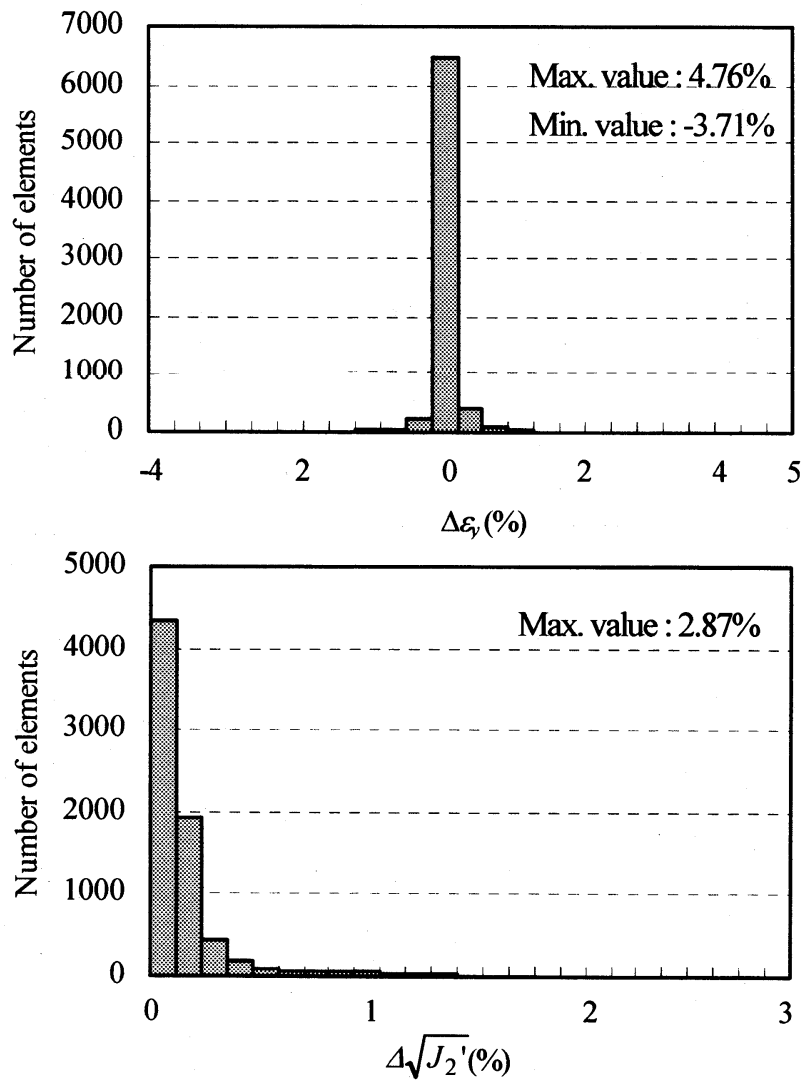

図-8 ひずみ増分のヒストグラム Casel 2-3 段階 


\section{2 空間統計解析}

（1）ひずみのグローバルな空間自己相関特性

$\Delta \sqrt{J_{2}{ }^{\prime}}$ の空間自己相関関係を調べるため、各荷重段階 での Moran's $I, I(d)$ を算定した。離間距離クラス $d$ に対する $\Delta \sqrt{J_{2}^{\prime}}$ の $I(d)$ を図-9 に示す。各要素の離間距離は要素中心 間の距離とした。また、図中の番号は図-4の応力ーひずみ 関係中の位置を示寸ものである。図-9より、載荷初期 2-3 段階において、 $\Delta \sqrt{J_{2}^{\prime}}$ の $I(d)$ は平均粒径の 2 倍程度の $d<2.0 \mathrm{~mm}$ の範用で正の相関を示し、それ以上の距離でほぼ 0 の無相関を示している。その後載荷に伴い $\Delta \sqrt{J_{2}{ }^{\prime}}$ の $I(d)$
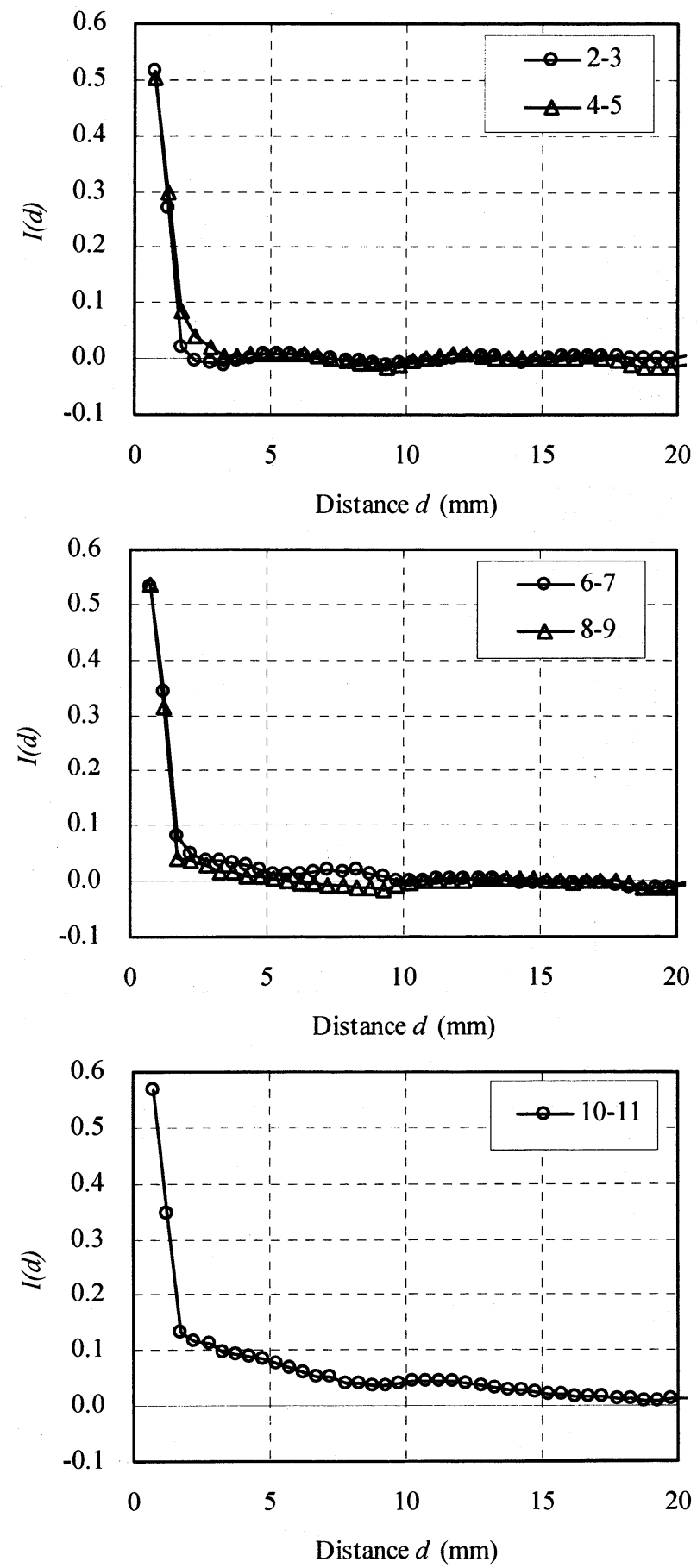

図-9 偏差ひずみ増分の Moran's I Casel
は大きく変化しており、マクロな応力一ひずみ関係におい て非線形性が卓越し始める 6-7 段階では、 $d<10 \mathrm{~mm}$ の範囲 で正の相関関係が見られる。ただし、その後の 8-9 段階で は、正の相関を示寸範用が $d<5 \mathrm{~mm}$ 程度に縮小している。 そして、ピーク応力後の 10-11 段階では、 $d<20 \mathrm{~mm}$ の範囲 において $I(d)>0$ と再び自己相関を示寸領域が拡大してい る。このように、 $\Delta \sqrt{J_{2}^{\prime}}$ のI(d)はプレピーク状態より載荷 に伴い大きく変化していることがわかる。

離間距離クラス $d$ に対する $\Delta \sqrt{J_{2}{ }^{\prime}}$ のGeary's $c, c(d)$ を図 -10 に示す。載荷初期、2-3 段階において、 $d=2 \mathrm{~mm}$ 程度で
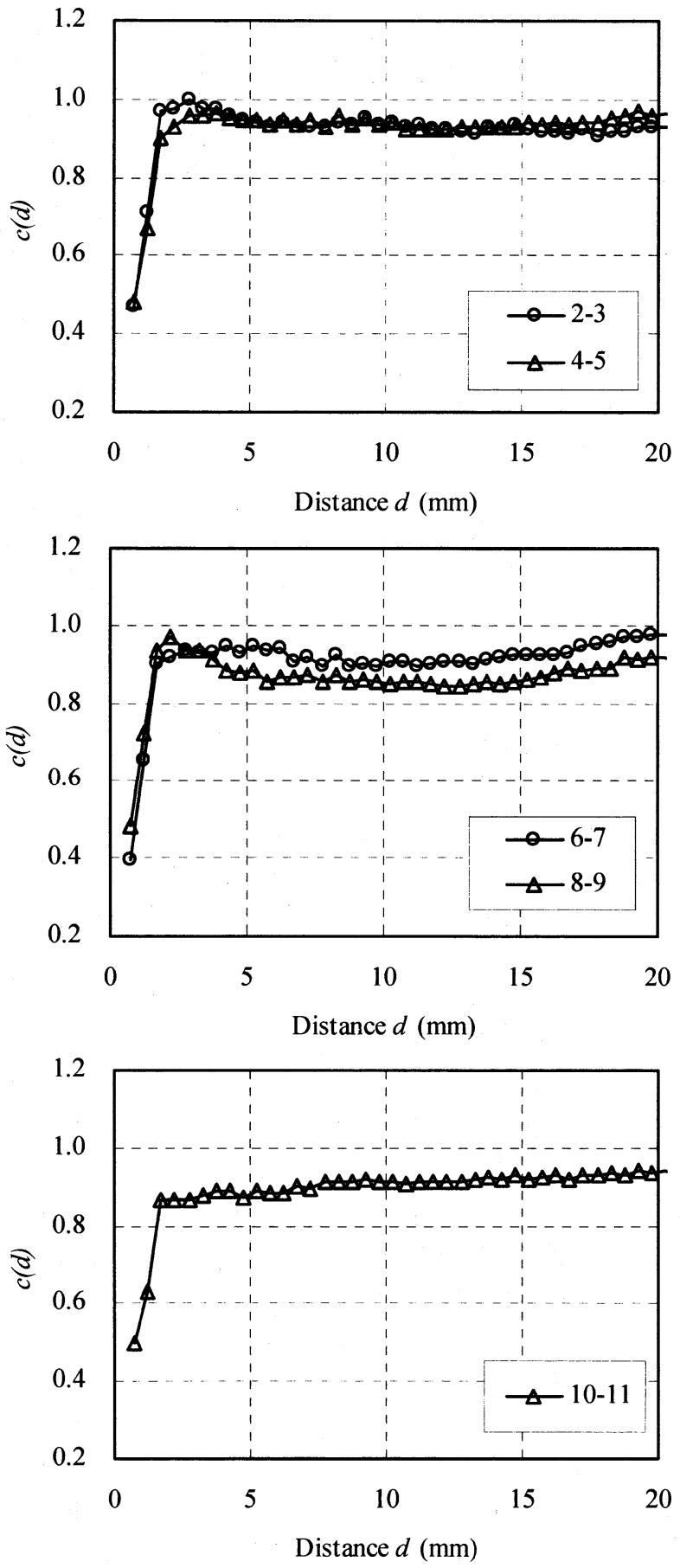

図 10 偏差ひずみ増分の Geary's $c$ Casel 
c(d)の值はほぼ 1 となっており、この段階での自己相関の 範用は $2 \mathrm{~mm}$ 程度あることがわかる。この值は、Moran's $I$ において無相関を示寸範用とほぼ一致している。その後、 Moran's $I$ と同様に載荷に伴い, $\Delta \sqrt{J_{2}{ }^{\prime}}$ ) $c(d)$ は変化する。 Moran's $I$ と Geary's $c$ と比較した場合、相関を示寸範用が 両者で異なるものの、定性的にはほぼ同じ傾向を示してい ることがわかる。

\section{（2）ひずみの自己相関を示す距離}

Moran's $I$ の結果を用いて $\Delta \sqrt{J_{2}}$ の自己相関距離を算 定した。前述したようにMoran's $I$ は $I(d)=0$ で無相関とな るが、図-9に示寸ようにひずみ分布より算定される $I(d)$ は 厳密に0となることはない。そこで、データをランダムに 再配置し、その自己相関のない 配置での Moran's $I$ との比 較より、各距離クラスでの自己相関に対する有意性の判断 をした (Fortin and Dale 2005 $\left.{ }^{14}\right)$ 。ここで、乗算合同法によ る擬似乱数により配置の入れ替え箇所を選定し、順次デー タを入れ替える手法によりランダム配置を行った。ランダ ム再配置の回数は 1000 回とした。

ランダム配置により得られる $\Delta \sqrt{J_{2}^{\prime}}$ の $I(d)$ の分布につい て検討する。例えば、Case1, 2-3 段階の距離クラス 1.5$2.0 \mathrm{~mm}$ での $\Delta \sqrt{J_{2}^{\prime}}$ の $I(d)$ の分布の場合、歪度は 0.19 、尖度 は 0.049 であった。これより、ランダム配置により得られ るI(d)はほぼ正規分布であることがわかる。そこで、ラン ダム配置により得られる $I(d)$ は正規分布であると仮定し、 自己相関性の有無に関する検定を行った。ここで、 $\Delta \sqrt{J_{2}{ }^{\prime}}$ の空間分布に自己相関性がないという帰無仮説に対し有 意水準 5\%の検定を行い、仮説が棄却される場合 $\Delta \sqrt{J_{2}{ }^{\prime}}$ の空間分布に自己相関性があると判断した。

自己相関性の検定例を図-11 に示す。これは Case1, 2-3 段 階の結果である。図には、ランダム配置から設定された有 意水準 5\%の基準を破線で示している。また、自己相関が あると判定された距離クラスは黒塗りで、自己相関がない と判定された距離クラスは白抜きで示している。距離クラ スにより自己相関性の有無が変化しているが、距離が長く なると相関があると判定されても基準との差はわずかで ある。そこで本研究では、自己相関が無くなる最小距離 (図 -11 では $2 \mathrm{~mm}$ ）を自己相関の範囲とした。

上記方法で算定した各ケースにおける $\Delta \sqrt{J_{2}^{\prime}}$ の空間自 己相関の範讲の変化を図-12 に示す。ここで、横軸は図-4 に示寸各載荷段階である。各ケースとも載荷に伴い自己相 関を示す距離は増加する傾向にある。ただし、自己相関の 範囲は単調に増加寸るのでなく、増减しながら増加してい る。特に、自己相関の範讲は 5-6 段階あたりより急激に大 きくなっているが、これはマクロな応力一ひずみ関係にお いて非線形性が顕著となる段階と一致している。

また、ケース間により自己相関の範囲の変化に差があり、 ほぼ同じ粒子数及び密度であっても配置が異なることに より載荷過程でのひずみ増分の空間相関特性が異なるこ とがわかる。そして、5-6 段階あたりから自己相関の範用
のケース間の差が大きくなるが、この段階ではマクロな応 カーひずみ関係においてもケース間で顕著な差が生じは じめている (図-4 参照)。Case2 において 6-7 段階では自 己相関の範用が $20 \mathrm{~mm}$ となっているが、この值は供試体幅

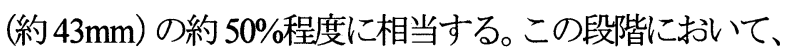
Case1 に比較し Case2 ではマクロな応力が明らかに小さく なっている (図-4)。これらの結果は、初期配置の違いに より供試体内に形成されるひずみの空間分布特性に違い が生じ、これによりマクロな応力ーひずみ関係に違いが生 じることを示唆している。

\section{（3）ひずみのロ一カルな空間自己相関特性}

ひずみが集中している領域を調べるため、 $\Delta \sqrt{J_{2}{ }^{\prime}}$ の Local Moran's $I, I(d)$ を算出した。Casel の 2-3, 6-7, 10-11 段階にお ける。 $I(d)$ を図-13 に示す。ここで、 $I(d)$ は距離クラス 4 -6mm の值を示している。距離クラスが異なる $I(d)$ につい ては後述する。

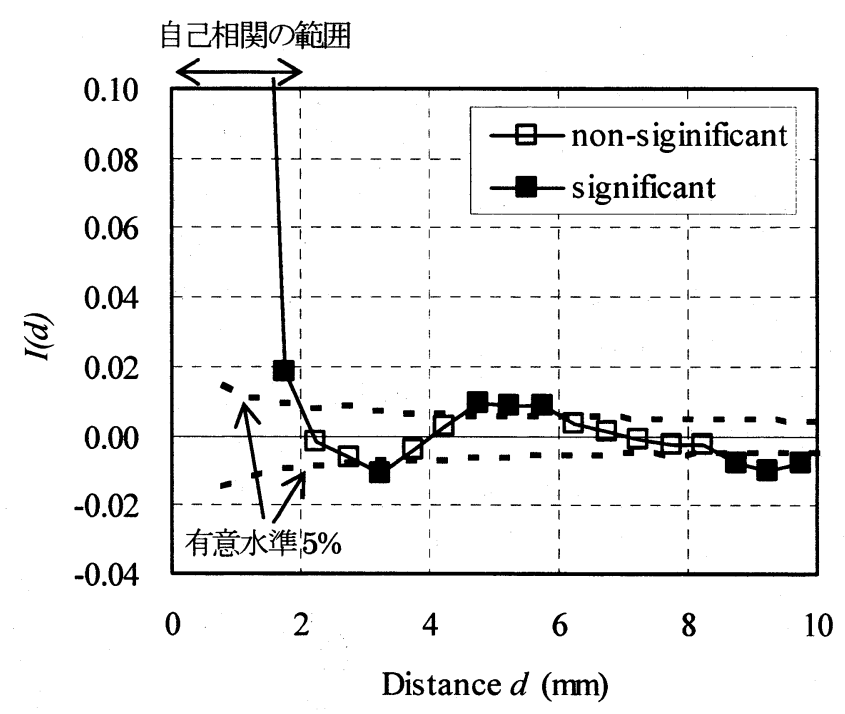

図-11 自己相関の有意性の判定 Casel 2-3 段階

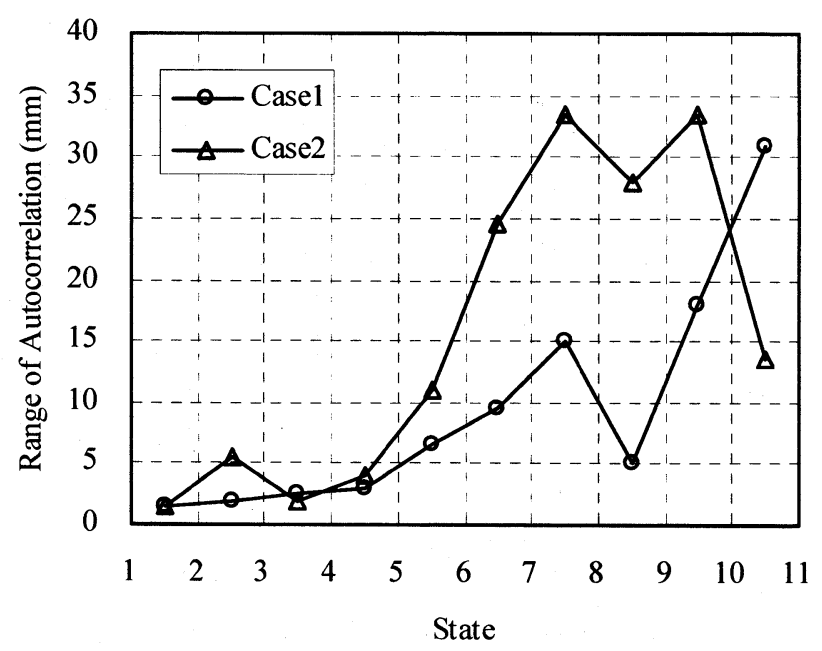

図-12 偏差ひずみ増分の自己相関の範囲 
図-13 より、載荷初期 2-3 段階においては $I(d)$ が大きな 值を示している箅所は分散していることがわかる。一方、 マクロな応力ーひず夕関係の非線形性が大きくなる6-7段 階では、供試体右中央部に $I(d)$ が大きな值を示寸箇所が 集中している。この領域は $\Delta \sqrt{J_{2}^{\prime}}$ の分布（図-7）において 大きなひずみが発生している領域と対応しており、大きな ひずみの集中領域であるといえる。ピーク荷重後の 10-11 段階では 6-7 段階とは異なる左下から右中ほどにかけて、 $I(d)$ が大きな值を示寸領域が帯状に伸びている。この領域 も $\Delta \sqrt{J_{2}^{\prime}}$ の分布 (図-7) において大きなひずみが発生し ている領域と対応しており、大きなひずみが集中する領域 が帯状に伸びていることがわかる。この領域はせん断帯に 相当するといえる。これら Local Moran's Iの結果は、プレ ピーク時より供試体内には大きなひずみが集中する領域 が発生すること、集中領域は載荷にともない変化しポスト ピーク時にはせん断帯を示唆する帯状の領域が発生する ことを明確に示している。

次に距離クラスによる集中領域の違いを図-14 に示す。 図にはCase1 の6-7段階における距離クラス4-6mm, 6-8mm, $8-10 \mathrm{~mm}$ での $I(d)$ が (平均值) + (標隻偏差の 2 倍) 以上 の值を示す要素を示している。前述したように距離クラス 4-6mm では供試体右中央部に $I(d)$ が大きな值を示す箇所 が生じている。そして、距離クラスが変わっても大きな值 を示寸領域はあまり変化しないことがわかる。このことは、 4-10mm の距離で強い相関性を示寸領域は供試体右中央部 であることを示唆している。

図-9 に示す Moran's $I$ より、Casel の 6-7 段階では $10 \mathrm{~mm}$ 程度の距離までグローバルな自己相関性を示しているこ とがわかるが、この相関性は供試体右中央部に生じている ひずみの集中領域に大きく起因していると考えられる。

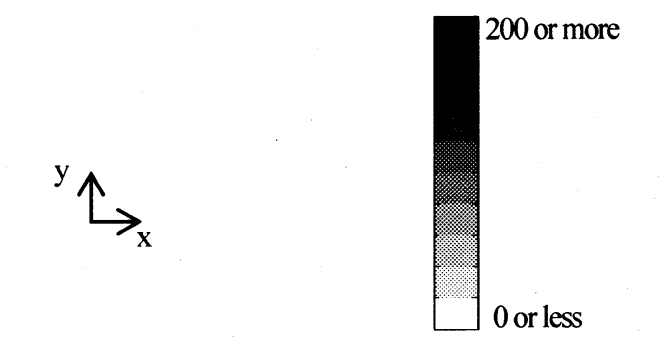

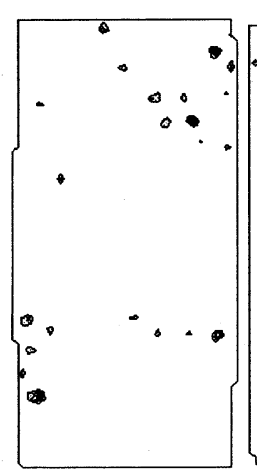

$2-3$

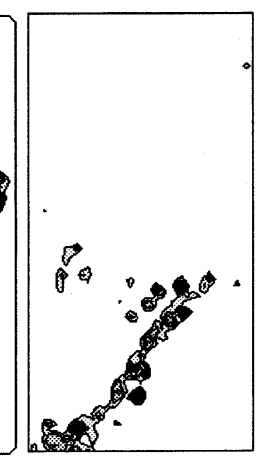

$10-11$
困-13 偏差ひずみ増分の Local Moran's $I$

Casel 距離クラス 4-6mm

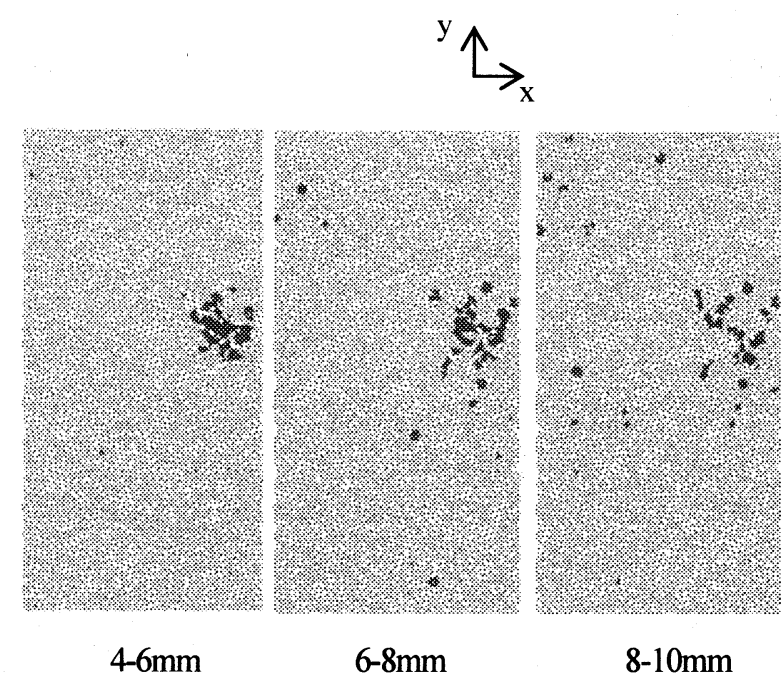

図-14 偏差ひずみ増分の Local Moran's $I$ が 大きな值を示す領域（着色部） Case1 6-7 段階

グローバルな自己相関性を検討する場合、供試体内ひず み分布の定常性が前提となるが、ひずみの集中領域が生じ ることにより定常性の仮定が成立しなくなっている可能 性もある。供試体内ひずみ分布の定常性は供試体変形の均 質性を示す指標と考えられ、載荷過程におけるひずみの集 中が生じる状況での空間分布の定常性の検討は今後の課 題といえる。

\section{4. まとめ}

個別要素法による二軸圧縮条件のシミュレーシ ヨンを実施し、得られた粒状体の動きから個々の粒 状体間の相対変位よりひずみ増分分布を算定した。 ひずみ増分分布の統計量の算出及び空間統計解析 を実施することにより、以下のことが明らかとなっ た。

- 個々の粒状体間の相対変位より算定される軸ひず み増分及び偏差ひずみ増分の度数分布は正規分布では ない。

- 個々の粒状体間の相対変位より算定される偏差ひずみ 増分の平均值はマクロな偏差ひずみ増分とは異なる。

・偏差ひずみ増分の空間自己相関を示す距離は載荷にと もない変化する。特にマクロな応力ーひずみ関係におい て非線形性が顕著となる段階で、偏差ひずみ増分の自己 相関距離は大きくなる傾向にある。

・プレピーク時においても、マクロな応力ーひずみ関係 において非線形性が顕著となる段階では、大きなひずみ が集中する領域が生じる。ポストピーク時にはプレピー ク時とは異なる位置にせん断帯を示す帯状のひずみ集 
中領域が生じる。

本研究により、 2 軸区縮過程の粒状体内の偏差ひずみ増 分分布の空間分布特性が変化することが明らかとなった。 このような空間分布特性の変化は、プレピーク時よりマク 口な応力ーひずみ関係に影響を与えると考えられる。

\section{謝辞}

Delaunay 三角形分割において (株) 竹中工務店 重 野喜政氏から提供して頂いたプログラムを使用し ました。ここに感謝の意を表します。

\section{付録}

要素面積が個々の粒状体間の相対変位より算定される ひずみの統計量に与える影響について検討する。表-3(b) に示す Casel の偏差ひずみ増分の統計量に関して、要素面 積を考慮した場合の平均值と分散を表-4に示寸。要素面積 を考慮した平均值と分散は次式で算定した。

$$
\bar{x}_{A}=\frac{\sum_{i}^{n} x_{i} A_{i}}{n \bar{A}} \quad \sigma_{A}{ }^{2}=\frac{\sum_{i}^{n} A_{i}\left(x_{i}-\bar{x}\right)^{2}}{n \bar{A}}
$$

ここで、 $A_{i}$ は要素 $i$ の面積、 $\bar{A}$ は要素面積の平均值である。 表-3(b)との比較より、偏差ひずみの統計量に関して、要素 面積考慮の影響はほとんどないことが分かる。表-4には各 要素の要素面積とひずみと要素面積の相関係数も合わせ て示している。ひずみと要素面積の相関係数もほぼ 0 で、 無相関であるといえる。

次に、要素面積が Moran's Iに与える影響について検討 する。式(1)において、重みを次式で算定することで、 Moran’s Iに要素面積を考慮した。

$$
w_{i j}=\frac{A_{i} A_{j}}{\bar{A}^{2}}
$$

Casel の 6-7 段階での Moran's Iについて、要素面積を考慮 しない場合と考慮する場合の比較を図-15に示す。両者は ほぼ一致しており、要素面積が Moran's $I$ にえる影響は ほとんどないことがわかる。

以上の検討結果より、本研究におけるひずみの統計解析 に要素面積が与える影響はほとんどないといえる。
表-4 面積を考慮した偏差ひずみ増分の統計量 Casel

\begin{tabular}{|c|c|c|c|c|c|}
\hline \multirow{2}{*}{$\begin{array}{c}\text { 載荷 } \\
\text { 段階 }\end{array}$} & \multicolumn{2}{|c|}{ 偏差ひずみ増分 } & \multicolumn{2}{|c|}{ 面積 $\left(\mathrm{mm}^{2}\right)$} & \multirow{2}{*}{ 相関係数 } \\
\cline { 2 - 5 } & 平均 & 分散 & 平均 & 分散 & \\
\hline $2-3$ & 0.175 & 0.0660 & 0.483 & 0.00755 & -0.0327 \\
\hline $4-5$ & 0.230 & 0.100 & 0.483 & 0.00753 & -0.0307 \\
\hline $6-7$ & 0.411 & 0.821 & 0.483 & 0.00750 & -0.0241 \\
\hline $8-9$ & 0.515 & 1.44 & 0.483 & 0.00745 & -0.0257 \\
\hline $10-11$ & 0.686 & 1.89 & 0.483 & 0.00748 & -0.0392 \\
\hline
\end{tabular}

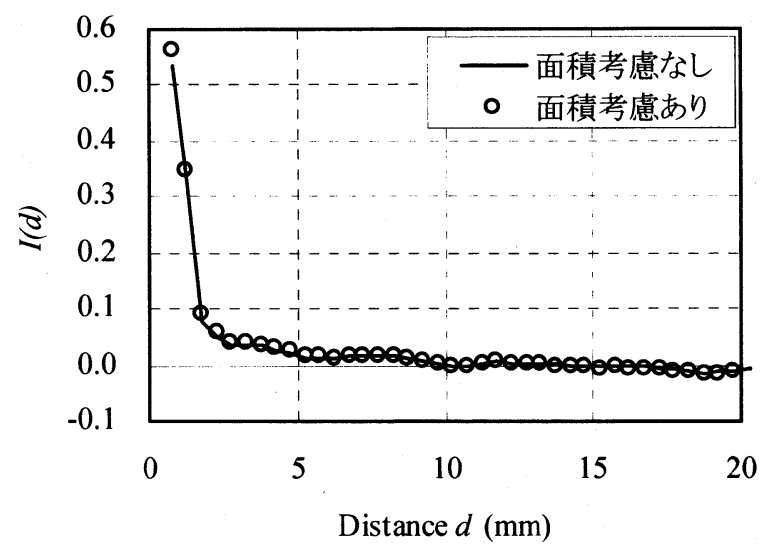

図-15 Moran’s $I$ への要素面積の影響 Case1 6-7 段階

\section{参考文献}

1) Han, C., Vardoulakis, I.G. : Plane-strain compression experiments on water-saturated fine-grained sand, Geotechnique Vol.41, No.1, pp.49-78, 1991.

2) Han, C., Drescher, A. : Shear bands in biaxial tests on dry coarse sand, Soils and Foundations, Vol.33, No.1, pp.118-132, 1993.

3) Yoshida, T., Tatsuoka, F., Siddiquee, M.S.A., Kamegai, Y., Park, C.S. : Shear banding in sands observed in plane strain compression, Localization and Bifuraction Theory for Soils and Rocks, pp.165-179, 1994.

4) Finno, R.J., Harris, W.W., Mooney, M.A., Viggiani, G. : Shear bands in plane strain compression of loose sand, Geotechnique, Vol.47, No.1, pp.149-165, 1997.

5) Alshibli, K.A., Sture, S. : Shear band formation in plane strain experiments of sand, Journal of Geotechnical and Geoenvironmental Engineering, Vol.126, No.6, pp.495-503, 2000.

6) Desrues, J., Viggiani, G. : Strain localization in sand : an overview of the experimental results obtained in Grenoble using stereophotogrammetry, International Journal for Numerical and Analytical Methods in Geomechanics, Vol.28, pp.279-321, 2004.

7) Cundall, P.A., Strack, O.D.L. : A discrete numerical model for granular assemblies. Geotechnique, Vol.29,No.1, pp.47-65, 1979. 
8) Bardet, J.P., Proubet, J. : A numerical investigation of the structure of persistent shear bands in granular media. Geotechnique, Vol.41,No.4,pp.599-613, 1991.

9) 松岡元，山本修一：個別要素法による粒状体のせん断 機構の微視的考察, 土木学会論文集, No.487, III-26, pp.167-175, 1994.

10)岩下和義, 小田匡寛: 粒子接点での転がり抵抗を考慮し た個別要素法によるせん断帯の微視的変形機構, 応用 力学論文集, Vol.2,pp.401-411, 1999.

11)大村篤史, 大野了悟, 櫻井崇之, 萩真次, 前田健一： DEM を用いたせん断層内の幾何学量に関する研究, 第 39 回地盤工学研究発表会, pp.397-398, 2004.

12)谷口健男 : FEM のための要素自動分割, 森北出版, 1992.
13)佐武正雄 : 講座 土の構造とメカニックスーミクロか らマクロヘー 3. 土のマクロメカニックス入門, 土と基 礎, 50-7, pp.49-54, 2002.

14)Fortin, M-J., Dale, M. : Spatial analysis - A guide for ecologists - . Cambridge University Press, 2005.

15)Wackernagel, H. (地球統計学研究委員会訳) : 地球統計 学, 森北出版(株), 2003.

16)Anselin, L. : Local indicators of spatial association - LISA, Geographical Analysis, Vol.27, No.2, 1995.

17)東京大学教養学部統計学教室編: 統計学入門 第 5 章 確 率変数, 東京大学出版会, pp.87-108,1991.

(2008 年 4 月 14 日 受付) 